\title{
Ung og etterlatt ved selvmord
}

Sarah D owkes intervjues av H eidi Ryste.

- Jeg var bekymret for foreldrene mine og syntes synd på dem, for jeg tenkte at det måtte vare enda verre for dem enn for meg. Jeg fryktet først at hele familien skulle gå i oppløsning, sier Sarah Dowkes. Sarahs søster tok sitt liv, og reaksjonene blant familiemedlemmene var vidt forskjellige. Når en familie blir rammet av et selumord, skaper det ofte spenninger i det vante samspillet. - Selv om familiebåndene fortsatt er sterke, endret sorgprosessen rollene og kommunikasjonen innad i familien, forteller Sarah Dowkes.

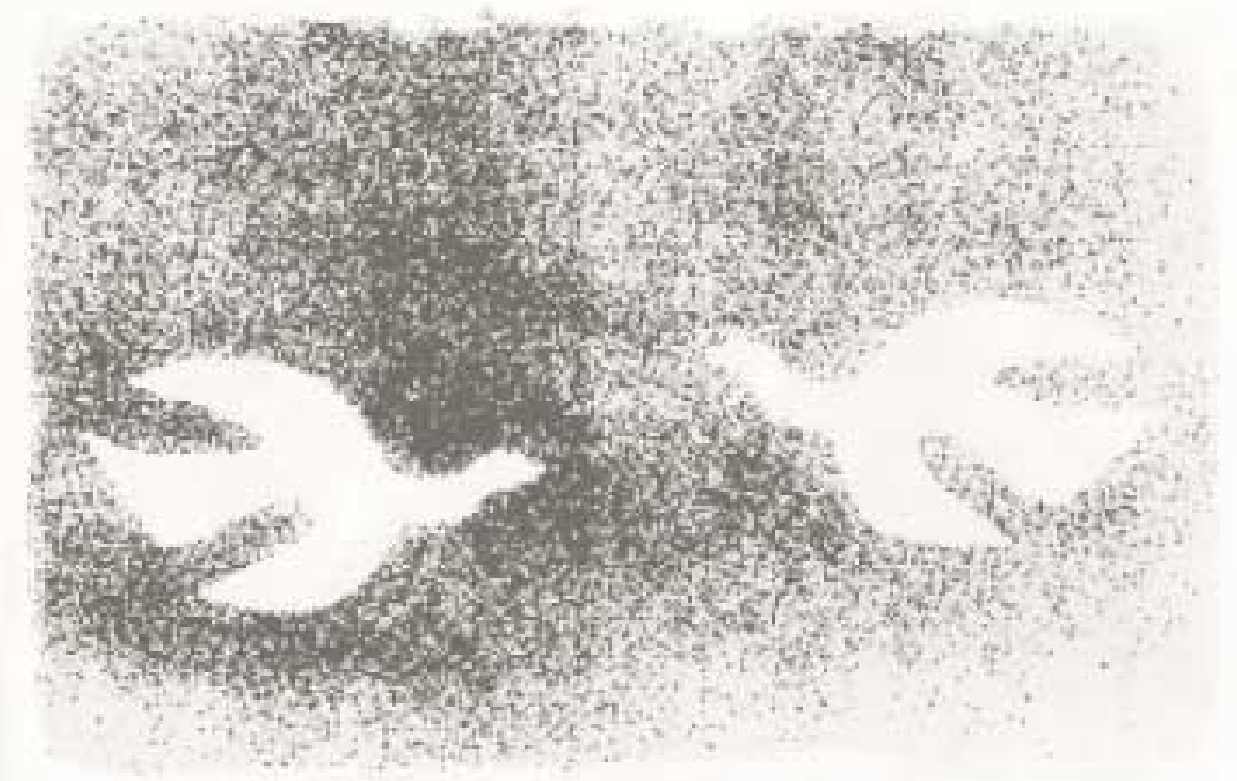

\section{Tomrommet i familien}

Da Sarah Dowkes (24) fikk beskjed om at søsteren Ingrid (21) hadde tatt livet sitt for snart ett år siden, fryktet hun først at hele familien skulle gå i oppløsning. De ulike familiemedlemmene reagerte svært ulikt og tok ulike roller, noe som først gjorde sorgprosessen svært vanskelig.

- Huset vi bor i har alltid vært et positivt hjem, og jeg har alltid vært glad i å være hjemme. M en like etter at Ingrid var død, tenkte jeg bare at dette er et hus som sørger. Jeg var bekymret for foreldrene mine og syntes synd på dem, for jeg tenkte at det måtte være en da verre for dem enn for meg. Vi har hele veien vært en veldig sammensveiset familie og hatt et svært godt forhold til hverandre, men nå ble jeg plutselig redd for hvordan det skulle gå med familien. Kanskje mamma og pappa kom til å skille seg? De er ganske forskjellige i utgangspunktet og reagerte veldig forskjellig, sier Sarah D owkes.

\section{Ulike reaksjoner}

A t et selvmord blir omtalt som en personlig tragedie er bare én dimensjon ved det som er skjedd. Det er selvsagt en tragedie, men ringvirkningene strekker seg langt utover den som har val gt å ta livet sitt. Familier som rammes av selvmord, sitter igjen med et tomrom som ikke kan fylles. M ens noen reagerer med sinne og frustrasjon, kan andre være rolige og handlingsrettet. Spenningene som skapes, kan giøre tida etterpå svært vanskelig for familier som sårt tren ger å stå sammen og støtte hverandre i sorgen.

- A lle reagerer så forskjellig at det lett kan bli veldige kommunikasjon sproblemer. Pappa var nesten helt manisk. $\mathrm{H}$ an snakket mye og klarte ikke å være i ro. $M$ amma var mye roligere. Jeg gikk noen

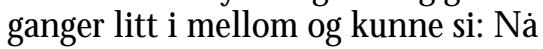
skjønner dere ikke hverandre fordi dere reagerer så forskjellig. J eg prøvde å megle og var redd for hvordan det skulle gå med oss, sier Sarah.

For ett år siden hadde ikke familien til Sarah opplevd at noen nære hadde tatt livet sitt. De hadde ikke opplevd at noen i familien hadde hatt kontakt med hjelpeapparat eller hatt psykiske problemer. De visste ikke at lillesøsteren Ingrid sannsynligvis var i ferd med å gå inn i en dyp depresjon, og at familien på fem snart skulle miste en datter og søster.

- Jeg tror ikke hun selv heller var klar over hvor syk hun var. Da hadde hun søkt hjelp, sier Sarah.

\section{Ingen anelse}

Både Sarah og Ingrid bodde i A ustralia i fjor. Sarah holdt på med masterstudier i marketing management ved $\mathrm{G}$ riffith U niversity, G old C oast, mens Ingrid studerte sykepleie i A delaide, to-tre timers flyreise unna. De hadde begge reist ned i januar 2003, men fordi avstanden mellom dem var så stor, så de ikke hverandre før i juli. Da kom Sarah en uke til A delaide sammen med en kamerat.

- Jeg visste at Ingrid var nedfor, men ikke at hun var så alvorlig deprimert. Det hadde jeg ingen anelse om. Jeg hjalp henne med en del praktiske ting, og hun sa at hun hadde det bedre og så mer positivt på framtida.

Tirsdag 15. juli dro Sarah tilbake til G old C oast. To dager senere tok Ingrid livet sitt mens romkameratene hennes var bortreist. Fredag fant to venner henne i garasjen i tilknytning til leiligheten, og natt til lørdag fikk Sarah telefonen fra N orge. Ingrid etterlot seg ikke noe brev eller forklaring.

- Jeg har alltid tenkt at det må være en helt åpenbar grunn til at noen tar livet sitt, men ingen kunne tenkt seg at Ingrid kom til å ta livet sitt. D et var utrolig sjokkerende for alle. $\mathrm{H}$ un var veldig bekymret spesielt på grunn av skolen. $\mathrm{H}$ un opplevde skolen som veldig tøff. Det var kanskje det som utløste selvmordet, eller det var i hvert fall en medvirken de årsak. 


\section{Profesjonell hjelp}

I N orge satt mor, far og lillebror på tolv år. Sammen bestemte familien at Sarah skulle komme tilbake til N orge så fort som mulig, og to døgn senere var hun tilbake hos familien. En sørgende familie som hun egentlig ikke skulle sett igjen før til jul.

\section{- Før jeg kom hjem, fokuserte jeg all} energi på å holde meg oppe og ikke bryte sammen. Jeg gledet meg veldig til å komme hjem, men til å begynne med var det veldig rart å være hjemme igjen. J eg skulle jo ikke vært hjemme før i desember. Jeg tok meg av mye av det praktiske og ble den som prøvde å organisere og fokusere på andre ting også. Etter et par dager hadde mamma og jeg planlagt hele begravel sen. Pappa gjorde ikke så mye av det praktiske i denne perioden. $\mathrm{H}$ an orket ikke det.

Ingen av familiemedlemmene fikk tilbud om hjelp umiddel bart etter dødsfallet. Likevel tok de aktivt kontakt med det profesjonelle hjel peapparatet.

- A lle i familien var positive til å få hjelp. M amma og jeg snakket med en dame i kirken. Jeg var i utgangspunktet positiv til profesjonell hjelp, men jeg trodde egentlig ikke hun kunne gjøre noe for meg. M en det kunne hun. Pappa begynte å gå til en psykolog jeg fant til ham. Det var midt i fellesferien, så det var vanskelig å få tak i en, og det var ikke noe særlig å gå gjennom Gule sider og forklare situasjonen vår gang på gang.

- Det er ikke noe automatikk i at man får hjel p når det skjer noe slikt i en familie, og jeg savner at man kan få mer informasjon og ikke aktivt må søke hjelp selv. Det hadde vært ideelt om det fantes noen som tok kontakt med deg med en gang og ga deg informasjon om hvor du kunne få hjelp.

Sarah følte også behov for å få mer informasjon om fenomenet selvmord. H un hadde aldri tenkt at det var noe som kunne angå henne.

- Jeg lurte veldig på hva som egentlig skjer med mennesker som ikke vil leve lenger, og brukte blant annet en psykolog til å fă svar på noen av spørsmålene mine.

\section{Intenst å vaere hjemme}

Både Sarahs walisiske slektninger og venner og familie i N orge kom på besøk i tida etter dødsfallet.
- Det ble intenst å være hjemme og vel dig slitsomt å forholde seg til så mange sørgende mennesker. Derfor trengte jeg avbrekk og var mye sammen med venner. Jeg ville fortsatt gjøre noen av de vanlige tingene. Vi er ikke skapt til å sørge 24 timer i døgnet, og jeg trengte å være litt normal. A lle har hele tiden sagt at jeg er så utrolig sterk som fullførte utdannelsen, men hva skulle jeg ellers gjøre? For meg har det aldri vært noe alternativ å legge meg ned og grine, selv om jeg jo gjør det av og til også. Jeg tror familien var litt redd for hvordan det skulle gå med meg etter hvert, for selv om jeg er en åpen person, så holdt jeg likevel mye av sorgen for meg selv. Det har nok vært litt vanskelig for dem siden de ofte ikke så meg da jeg hadde mine reaksjoner. Samtidig var jeg bekymret for dem, uten at jeg egentlig snakket så mye med dem om det.

For Sarah var det viktig å leve videre, og dette innebar å fortsette studiene i A ustralia. H un hadde et halvt år igjen, og etter en måned i N orge var hun på vei tilbake til G old C oast. H un kontaktet en psykolog på skolen, og gikk i terapi i tre måneder. $\mathrm{N}$ å da familien var langt borte, ble vennene desto viktigere.

- A lle jeg kjente i A ustralia hadde jeg bare kjent i seks måneder, og det var en utfordring. De hadde bare kjent meg som en som var glad, positiv og med på det som skjedde, men nå måtte jeg vise dem at jeg trengte hjelp. Folk vil så gjerne hjelpe, men du må tørre å spørre om det. Jeg kan ikke regne med at folk skal vite hvordan jeg har det om jeg ikke sier det. Spesielt nà som det er gått gan ske lang tid og det er naturlig at andre ikke er så opptatt av det som jeg er.

\section{Reaksjonen}

Før Sarah reiste tilbake til N orge, dro hun på en måneds ferie med en venninne. Så kom jula, hun fikk seg jobb i O slo og flyttet inn i egen leilighet. Tida gikk fort. I februar kom reaksjonen.

- Jeg skjønte ikke hvorfor jeg var så sliten hele tida. Så en dag da jeg kjørte til jobb og det var fint vær med masse snø og nydelig hvitt, tenkte jeg: Ingrid får aldri oppleve dette mer. Det tar litt tid før man oppfatter ting og tar dem innover seg. Da jeg kom på jobb den dagen, brøt jeg helt sammen og tenkte bare at jeg måtte hjem.

Sarah ble sykemeldt og dro hjem til familien. I nesten tre uker var hun så psykisk og fysisk utslitt at selv de minste anstrengel ser ble van skelige.

- Det var veldig bra å komme hjem til det gamle rommet mitt. $0 \mathrm{~g}$ for resten av familien tror jeg det var litt godt à se at jeg også reagerte og hadde det vondt, selv om jeg hadde sørget i månedene før også. Familien på fire har fortsatt sterke bånd, selv om Sarah nå bor for seg selv i 0 slo igjen. Blir dagene for tunge reiser hun hjem til familien, og de har nesten daglig telefonkontakt.

- Den største utfordringen for oss er å takle høytider, å finne tilbake til en ny normal, for familien blir aldri som den har vært før. Heldigvis er det ingenting som har vært tabu å snakke om i familien, verken før eller nå, men det er utrolig tøft å se foreldrene sine lide på den måten samtidig som du har din sorg.

\section{Vilje til liv}

Familien gikk aldri til familieterapi med problemene de hadde rett etter selvmordet. M oren går fremdeles til samtaler, og Sarah har begynt å gå i sorggruppe for etterlatte etter selvmord. H un har også hatt kontakt med Leve, og har lyst til å engasjere seg i U nge Leve når hun orker det. Lillebroren ønsker ikke å få profesjonell hjelp, og familien ønsker ikkeå presse ham fordi det virker som han har det bra.

- D et er en stor sorg som preger hele familien. N oen som burde vært der, er ikke der lenger. $\mathrm{H}$ va annet er annerledes? Jo, vi har fătt hund! Samson. D et har vært kjempebra. H ele familien bestemte seg for det rett etter at Ingrid var død, og det har vært utrolig positivt. A lle i familien har hatt hjelp av det. M amma og Pappa har vært veldig opptatt av at de skal ha et godt liv videre også, og i påsken for eksempel, hadde vi det kjempefint sammen. Jeg tror det har vært viktig for oss som familie å stå sammen om å ville ha et godt liv i framtida også. Savnet vil alltid være der, men jeg vet at Ingrid ikke ville at vi skulle lide fordi hun tok livet sitt. Jeg er opptatt av at livet mitt skal gå videre. Jeg var bare 23 år da det skjedde, og jeg har alltid hatt det veldig bra og vil fortsette med det. Jeg vil ikke la dette få lov til å ødelegge meg selv om jeg blir veldig berørt, sier Sarah.

H eidi Ryste er frilansjournalist og skriver blant annet for LEVE-N ytt. 